\title{
Ibn 'Arabi and Spinoza on God and the World
}

\author{
Muhammad Kamal \\ Asia Institute, The University of Melbourne, Melbourne, Australia \\ Email:muhammad@unimelb.edu.au
}

How to cite this paper: Kamal, $M$. (2017). Ibn 'Arabi and Spinoza on God and the World. Open Journal of Philosophy, 7, 409-421.

https://doi.org/10.4236/ojpp.2017.74021

Received: June 28, 2017

Accepted: September 11, 2017

Published: September 18, 2017

Copyright (c) 2017 by author and Scientific Research Publishing Inc. This work is licensed under the Creative Commons Attribution International License (CC BY 4.0).

http://creativecommons.org/licenses/by/4.0/

\begin{abstract}
This paper is a comparative analysis of Ibn 'Arabi's and Spinoza's interpretation of God's existence and its relation with the world. The focus will be on the ontology of these two thinkers from different intellectual traditions, elucidating their tripartite system in order to find out whether the reality of the world in its relationship to God is denied or affirmed. To vindicate the similarities between the ontological views of Ibn 'Arabi and Spinoza this paper argues in light of God's simplicity and causality that the existence of the world can be understood by denying and affirming its identity with God.
\end{abstract}

\section{Keywords}

Existence, Substance, Simplicity, Causality, Unity, Difference, Theophany, Transcendence and Immanence

\section{Introduction}

Some scholars and critics refer to Ibn 'Arabi and Spinoza as pantheist philosophers who identify God with the world, failing to draw any distinction between the two. I argue however that in the ontological systems of these two thinkers the world is neither identical to God nor different. When the singular nature of Reality is asserted, the materiality of the world cannot be seen to be distinct from it. Regarding this ontological account of the nature of Reality, I will explore the affinity between particular aspects of Ibn 'Arabi's and Spinoza's views on God's relationship with the world. This exploration will be tempered with an awareness of the differences concerning their methodology, epistemology and adherence to religious texts. Unlike Spinoza, Ibn 'Arabi, is a mystic-philosopher and he relies on intuitive knowledge to comprehend Reality. For him, it is the "Heart" and not "Reason" that produces true knowledge about God and the heart alone is capable of accessing the divine realm (Ibn 'Arabi, 1980: p. 148). Accordingly, Ibn 'Arabi does not express his ideas in discursive rationalistic arguments. He discloses 
them in mystic experiences. When Ibn Rushd, a Peripatetic Muslim philosopher, met Ibn 'Arabi and was told about his spiritual experience, Ibn Rushd commented on Ibn 'Arabi's spiritual experience saying that "this is a state that we had confirmed rationally, but we had never seen anyone who possessed it" (Chittick, 1989: p. xiv). Henry Corbin also confirms Ibn 'Arabi's encounter with Ibn Rushd and cites him saying that "such a thing was possible, but [he had] never met anyone who had actually experienced it" (Corbin, 1981: p. 42). By contrast, Spinoza is a rationalist thinker, relying on "reason" for knowing Reality and using the geometrical method in his Ethics for justifying his ideas. Ibn 'Arabi often employs the terminology of theologians to describe the nature and attributes of God, and supports his views by quoting from the Qur'an, whereas Spinoza minimises the use of theological terms and does not refer to a religious text for reinforcing his arguments.

\section{God's Simplicity and Causality}

From the outset it is necessary to understand that for both thinkers there is a single ontological reality upon which everything stands. In Ibn 'Arabi's ontology, this single reality is called "Existence" and for Spinoza it is "Substance". The two different terms are employed to signify the same reality, as both terms refer to God. The existence of Godas the only reality, is therefore a common ground for them. It is this claim about the existence of a single ontological reality that has led scholars to call Ibn 'Arabi the founder of the doctrine of the Unity of Existence (wahdat al-wujûd), and Spinoza a pantheist philosopher. But neither Ibn 'Arabi nor Spinoza used these terms to describe their doctrines, and the term "Pantheism" suggests a somewhat simplified version of their respective ontologies. It is also possible to argue that Ibn 'Arabi, like Spinoza, accepts the reality of a single "substance" as he rejects individual substances as advocated by Aristotle and some Muslim theologians. According to him, all individual substances are mere accidents and effects rather than substances. God who is a self-caused being and immutable, can only be defined as substance. All existing entities which are called substances by Aristotle and some theologians, are not different from accidents in being caused and in constant change (Chittick, 1989: p. 97). The term wahdat al-wujûd, which describes Ibn 'Arabi's ontological position, was coined after him. It was taken up by his opponents, particularly the orthodox theologians Ibn 'Abd al-Salam al-Sulami (d. 1262) and his contemporary the jurist Ibn Taymiyya, (d. 1328). The former declared Ibn 'Arabi "a master of evil" (Knysh, 1999: p. 66) and the latter branded the doctrine of the Unity of Existence heretical or atheism (Knysh, 1999: p. 94). Ibn Taymiyya stated also that in Ibn 'Arabi's philosophy, the world is identical to God's existence and both were seeing as eternal and such belief surpassed in unbelief. Not surprisingly, the dispute around Ibn 'Arabi's ontology has led to conflicting views. Some scholars have agreed that the term "Pantheism" is rightly applied to Ibn 'Arabi's ontology, while others find it inadequate. Abul Ela Affifi, whose contribution to the 
study of Ibn 'Arabi's thought is significant, has no hesitation in employing the term "Pantheism" to describe Ibn 'Arabi's ontology (Netton, 1980: p. 272). Others, such as Hussein Nasr and Chittick do not favour the term "pantheism" and insist that it should not be attributed to the doctrine of the Unity of Existence (Chittick, 1989: p. 79). Comparable controversy surrounds Spinoza's ontology. Hegel, in his lectures on the history of philosophy associates Spinoza's system with absolute pantheism and monism. He also explains how Friedrich Heinrich Jacobi identifies Spinoza's thought even with atheism (Hegel, 1995: p. 282). Bertrand Russell, in interpreting Spinoza's philosophy, remarks that "although his whole philosophy is dominated by the idea of God, the orthodox accused him of atheism" (Russell, 2000: p. 552). As we know, on July 27, 1656, Spinoza was excommunicated by the Ark in the synagogue of Talmud Torah, the united congregation of the Portuguese Jews in Amsterdam. The document of excommunication, which was written in Portuguese, states;

"The chiefs of the council do you to wit, that having long known the evil opinions and works of Baruch de Espinoza, they have endeavoured by diverse ways and promises to withdraw him from evil ways, and they are unable to find a remedy, but on the contrary have had every day more knowledge of the abominable heresies practiced and taught by him." (Pollock, 2005: p. 47)

The charge against Ibn 'Arabi and Spinoza by orthodox theologians is to some extent not speculative or baseless as an interpretation of the existence of God and its relation with the world by them is in contradiction with the views of these theologians. However, the criticism of the orthodox theologians and the challenges posed by them are connected with the notion of God's simplicity, His causal relationship with the world and its location, for example, whether God is transcendent or immanent. In defining God as an object of mystic knowledge, Ibn 'Arabi combines the notions of nondelimitedness, cause and effect, essence and existence. All these refer to God's simplicity and causal relationship with the world. God's existence as the ultimate reality is limitless and hence remains absolute, but His ontological priority asserts His unity, which makes Hima simple being. For this reason God's essence is not separated from His existence. In The Meccan Revelations Ibn 'Arabi writes,

"Know that the objects of knowledge (al-ma' humât) are four. [The first is] God, who is described by Nondelimited Being (al-wujûd al-mutlaq), for $\mathrm{He}$ is neither the effect (ma' $\hat{l} I$ ) nor the cause ('illa) of anything. On the contrary, He exists through his essence. Knowledge of Him consists of knowledge that $\mathrm{H} / \mathrm{he}$ exists, and His existence is not other than His Essence, though His Essence remains unknown; rather, the attributes that are attributed to Him are known, i.e., the Attributes of Meaning (sifât al-ma âní), which are the Attributes of Perfection (sifât al-kamâl)." (Ibn 'Arabi, 1980: p. 33) 
The ontological priority of God follows necessarily from this notion of simplicity because if God is composite and not simple then His existence will presuppose its components, and in this case God cannot become the ultimate ontological reality. The simplicity of God is by no means only a philosophical problem. It has also become central for Muslim theologians in their discussion of the reality and eternity of God's attributes, particularly between the rationalist and traditionalist theologians. Unlike the traditionalists, the rationalist theologians, represented by the Mu'tazilites, denied the reality and eternity of separate attributes in the essence of Goduntil a subtle balance was found by the Ash'arite theologians who adopted a theological position between orthodoxy and rationalism, between the unity of God and His attributes.

For Spinoza whatever is, is either God, His attributes or the modes of His attributes. In Ethics, he states, "God or substance consisting of infinite attributes, each of which expresses eternal and infinite essence, necessarily exists" (Spinoza, 1970: p. 7). God necessarily exists or is the Necessary Being because His existence and essence are one and the same thing. For, if God's essence does not involve existence, then God will become composite and cannot have ontological priority of existence. The distinction between existence and essence pertains to possible beings. God as the only substance is not produced from anything else and His essence must be His existence, "God's existence and essence are one and the same thing" (Spinoza, 1970: p. 19). Here, Spinoza, like Ibn 'Arabi, in order to affirm the ontological priority of substance he defends the unity and simplicity of God.

It is worth mentioning that the simplicity of God in Ibn 'Arabi's and Spinoza's ontology, which is based on the denial of any kind of inner dichotomy of Reality, is distinct from the simplicity of the "prime cause" in Aristotle's metaphysics and God in the doctrine of the theologians. For Aristotle, God is necessarily simple otherwise it will not be conceived as the first cause. Its simplicity is a mere reduction of its existence into a single element, namely a substance consisting of form without matter (Aristotle, 1995: 1032b1, 30). In the same manner, the simplicity of God's existence, for the theologians, excludes the materiality of the world. The world as something material remains completely different as well as separate from God. This interpretation of God's relationship with the world by the theologians is not different from Aristotle's doctrine of causation or the generation of the world by the prime cause. But Aristotle, unlike the theologians, does not advocate the idea of creation ex nihilo. For him the world as a hylomorphic reality has not come into existence out of nothing. The prime matter (hyle) which constitutes the physical aspect of the world, is neither from God nor created ex nihilo. For, according to Aristotle, it is not possible for something to be produced exnihilo and at the same time the prime matter is not from God because God is pure form. Prime matter, therefore, must have existed eternally with God, for what is uncreated has no beginning, and for Aristotle, the prime matter is uncreated. This metaphysical position however, is in conflict with the doctrine of creation ex nihilore inforced by the theologians. Nevertheless, for 
Aristotle and the theologians, God remains immaterial and His existence does not involve matter. Aristotle and these theologians sustain the unity and simplicity of God's existence by isolating matter from the pure form of God. Ibn 'Arabi and Spinoza oppose this understanding of God's simplicity because it does not include the material aspect of the world. If the material existence of the world is not contained in God then it should have its own reality distinct from God. In this case the idea of God's unity will be jeopardised. But, what does Ibn 'Arabi mean by defining God as neither the effect nor the cause of anything? Or in what way is God not a transient cause?

\section{God and the World}

Ibn 'Arabi, in explaining the causal relationship between God and the world, holds the view that everything is God and yet not God, because God is the only Reality and the ontological foundation of everything that exits. He illuminates this ontological position with a statement " $\mathrm{He} /$ not $\mathrm{He}$ "; signifying that whatever is, is God and yet not God.

"The Realty is at once the created Creator and the creating creature. All this is One Essence, at once Unique and Many, so consider what it is you see."

(Ibn 'Arabi, 1980: p. 87)

The Reality is manifest and unmanifest, the inner and outer. Whatever is found and experienced constitutes a sensory realm and the appearance of Reality. Similarly, God for Spinoza is "natura naturans", nature producing nature or a cause that produces nature but the caused nature "natura naturata" is not separated from its cause. It is in God and cannot be conceived without its cause (Spinoza, 1985: p. 91). It is impossible to think about the existence of anything without being part of God's existence and being conceived without it. But, can the world as something other than God have its own reality? To answer this question it is important to know how God's existence is interpreted in the philosophy of Ibn 'Arabi and Spinoza.

Once again in Aristotle's metaphysics and the doctrine of the theologians, the concept of God is defined by immateriality and transient causality. Immateriality pertains to God's singularity and simplicity, whereas causality signifies God's power to create the world and rule it without being involved in it. In opposition to these views Ibn 'Arabi believes that God is neither the effect nor the cause and Spinoza rejects the idea of transient causality, "God is the indwelling and not the transient cause of all things" (Spinoza, 1970: p. 18). By indwelling and not transient it is meant that all things that exist are in God, and none of them would be conceived without God. Since God's existence is the only ontological reality and the basis for the essence and existence of all existing entities it cannot be thought of as the effect or something produced by a cause. Whereas ontologically the reality of the world depends on God's existence. This dependence of the world on God is not analogous to the causality described by Aristotle and the theologians. God is definitely the cause of the world and no other cause coexists with Him. 
Yet God's causality must encompass everything, including the materiality of the world.

"The cosmos is the sensory realm [both subtle and gross] and the Vicegerent is unseen. For this reason the Ruler [God] is veiled, since the reality has described Himself has being hidden in veils of darkness, which are the natural forms, and by veils of light, which are the subtle spirits. The cosmos consists of that which is gross and that which is subtle and therefore, in both aspects, the veil [covering] its [own] true self [reality]." (Ibn 'Arabi, 1980: p. 56)

The world is God's sensory realm or the manifestation of His existence. Whatever exists displays the existence of God. Ibn 'Arabi also states,

"Then God manifested Himself in theophany through His Light to that Dust which is called by the people of reflection (ashâb al afkâr) "Universal Hylê" (al-hayûlâ al Kull); within the Dust was the entire world in potentiality (quwwa) and readiness (salâhiyya).” (Ibn 'Arabi, 2005: p. 26)

The material world has been produced by God and is an aspect of His self-manifestation. It is in this context that God is not defined as a cause in the Aristotelian or theological sense. Cause and effect can be understood to be both one and the same thing yet simultaneously they are different. It is also important to know that the sensory realm does not represent the "totality" of God's existence and is also not God. Rather the world is a "veil". Ibn 'Arabi does not establish an "absolute" identity between God and this veil and at the same time this veil prevents us from seeing the face of God. This incomparability of God with the world is again based on the notion of causality and the suggestion that God is both immanent and transcendent.

We can understand the identity and difference between God and the world in Ibn 'Arabi's ontology through the relationship between the Necessary Being and possible existents. The ontological necessity of God's existence for the world makes the world a possible being. This possible being undergoes generation and degeneration forever. The existing entities come into being in the world and become non-existents but never disappear because their "meanings" are fixed eternally in God's mind, and nothing in God's mind is perishable.

"It has been established that Being is God Himself ('aynal-haqq) and that the constant variation (tanawwi') in the forms manifested within it is a mark of the properties of the immutable entities of the possible things (a yân al-mumkinât al-thâbita).” (Ibn 'Arabi, 2005: p. 24)

In creation, these immutable entities (fixed ideas) become actual and receive spatial and temporal existence. The transformation of these immutable entities into particular existents in succession in the world leads to a constant flux of new creations. The immutable and existent entities are the same but the former are non-existents in the world. This mode of non-existence is crucial for the ori- 
gin of the world. It shows that the world is created ex nihilo with no prior material cause in an Aristotelian sense. At the same time "ex nihilo" does not mean absolute nothingness because whatever has come into existence was in God's mind from eternity. In dealing with the ontological status of the immutable entities Chittick refuses to compare them with Platonic universal forms, stating that the immutable entities are things before they are given existence in the world, as opposed to Platonic universal forms which resemble the divine names (attributes) (Chittick, 1989: p. 84). All temporary existing entities in the world then, were immutable before they were generated by God. They existed ideally in God's mind, which is equal to non-existence in the sense that they existed in God's mind eternally but not externally. Are the immutable entities non-existents? If we think of an entity as something that exists only in space and time then the immutable entities will become non-existents. But this understanding of an entity in Ibn 'Arabi's philosophy is inaccurate, because the immutable ideas are entities and do exist in a different mode. From this a new conclusion can be drawn regarding the origin of the world. We can presume that the world has existed eternally as an immutable entity. The term "non-existence" then becomes relative because these entities have possessed a different mode of existence before they were generated by God.

When we analyse Spinoza's ontology it becomes apparent that God is the only substance whose essence involves existence, and is something in itself. Spinoza also adds to this definition of substance by further stating "and is conceived through itself". Since substance stands by itself and does not rely on anything to support its existence, it must be conceived through itself rather than through something else. The term "substance" in this sense is applicable only to God, and not to the world or to the existing entities, which are neither in themselves nor conceived through themselves, "Except God no substance can be granted or conceived" (Spinoza, 1970: p. 11). As discussed before, Ibn 'Arabi rejects the substantiality of individual entities. For him God is by definition the only substance. This ontological position is also a clear departure from the Aristotelian tradition, which speculate upon the existence of more than one substance.

Spinoza argues for simplicity of substance. For if substance is not considered as simple then the parts will either retain the nature of substance or they will not. In the first case, each part must be infinite and self-caused. This is not possible because it gives rise to plurality of substances. If we assume that the parts do not retain the nature of substance and hence they have nothing in common with it, then substance and the parts could exist independently and be conceived without each other. This conclusion, like the previous one, is not reasonable and

"Hence it distinctly follows that (1) God is one alone, i.e., there is no like him, or in the nature of things only one substance can be granted, and that it is absolutely infinite, as we intimated in Note of Prop. 10." (Spinoza, 1970: p. 11)

The simplicity of God's existence or substance, which guarantees His unity, is 
on the one hand numerical in the sense that the number of substances is reduced to one. On the other hand, this simplicity, discussed by both thinkers, is based on the unity of God's essence with existence. But does the multiplicity of existing entities or the division of the material world impact on the simple nature of God? Or what is God's relationship with the multiplicity of all possible existents in the world? Spinoza's answer to this question is based on the relationship between "natura naturans" and "natura naturata", which is similar to Ibn 'Arabi's analysis of the relationship between the originator and originated. The world exists because it has been produced by God and both havesimilarity. If we think of God as the cause of the world and the world as having nothing in common with its cause, then God cannot be considered the cause of the world. Things having no causal relationship and nothing in common between them cannot be known reciprocally through each other. On the other hand if God's causality is immanent then the world is not separated from God after being produced and it is a part of God and is in God, "Whatever is, is in God, and nothing can exist or be conceived without God" (Spinoza, 1970: p. 11). This is the rejection of the Aristotelian concept of the transient causation and Cartesian dualism, which make a distinction between corporeal and incorporeal substances and separates the world form God. If the idea of immanent causality described by both Ibn 'Arabi is not understood correctly, it may lead to a misconception about God's existence as the "totality" or an "aggregation" of all existing entities, and hence there will be no distinction between God and the world. But, even with this imperative difference between God and the world, God's existence does not omit materiality of the world.

Edwin Curley refers to two interpretations of God's relationship with the world in Spinoza's ontology. The first is "The Bayle-Joachim Interpretation" and the second is by Harry Wolfson. The Bayle-Joachim Interpretation is rooted in the seventeenth century account of substance, particularly by Descartes and Locke. Curley summarises this account of substance in five assumptions: A substance is the subject or substratum in which all qualities inhere; a substance of a particular kind is a collection of qualities, together with the substance in which they all inhere; the substance in which all qualities inhere does not itself inhere in anything else, and hence it exists in itself; the subject unites into one thing the qualities which inhere in it and cannot be conceived as subsisting by themselves; finally, the existence of a substance must be inferred from the qualities we perceive (Curley, 1969: p. 4). This understanding of substance by the seventeenth century philosophers, which in my opinion, harks back to Aristotle's definition of a primary substance given in the Categories, has led Bayle to describe Spinoza's God as the subject of all propositions wherein the predicates inhere, without being itself in anything. In this way, all qualities, whether contradictory or consistent, including moral abominations, must be ascribed to God, and Curley in showing the inclusion of moral abominations states that in light of the Bayle-Joachim interpretation; 
"We can no longer say that Brutus killed Caesar, we must say that God killed Caesar. Nor, for that matter, can we say that Caesar was killed by Brutus. We must have it that God was killed by Brutus, or rather that God killed himself." (Curley, 1969: p. 12)

Against the Bayle-Joachim interpretation, Curley argues that these consequences are not even with Spinoza's understanding of God's existence and its modes. His argument is based on God's immutability provided in corollary II, of proposition XX, where Spinoza states that God and His attributes are unchangeable. But the attribute of human sins and moral abominations, as written by Spinoza in his letter (number 23) to William De Blyenbergh, are defined as mere negation. Whatever involves negation cannot be attributed to God because God is absolute positivity (Curley, 1969: p. 13). It is also obvious that Spinoza's definition of substance as something "conceived through itself" is in contradiction with the fifth assumption that the subject or substance must be inferred from its qualities we perceive. In addition to this, a substance is prior to its modifications and this priority is not only logical but ontological as well. Consequently, our knowledge of a mode entails the existence of a substance as a prior cause, our understanding of the world necessarily requires an understanding of God's existence. Wolfson rejects the Bayle-Joachim interpretation and traces back the definition of substance to the Jewish medieval thinkers and Aristotle rather than to Descartes and Locke. He explains how Spinoza's substance denotes the summumgenus and not a subject of logical propositions, and the relation of substance to its modes as a relation of genus to its species (Wolfson, 1962: pp. 76-78). The summum genus includes all species and individual modes but itself is not included in any genus. Curley however, disagrees with Wolfson and states that Spinoza did not regard substance as the summum genus (Curley, 1969: p. 35). There is another reason to believe that Spinoza did not describe substance as the summum genus. For example, the essence of an existing entity is revealed in a definition, which is depicted by Aristotle as (per genus etdifferentiam), if God is the summum genus then God would remain indefinable because God has neither genus nor differentia. But Spinoza does not claim that substance or God is undefinable. He proposes a new way to define God and that is through the divine attributes because these attributes constitute God's essence.

To maintain the simplicity of God the independent existence of the world must be denied. This denial provides an internal consistency to the ontological expositions of Ibn 'Arabi and Spinoza. God is recognised as a single reality that comprises everything, including the materiality of the world. This way of understanding God's existence and its relation to the world is in contradiction with the Aristotelian metaphysics and the theological notion of God as a being free of matter. But the question that arises here is how does the world exist? How is it different from God? Ibn 'Arabi and Spinoza have provided a new interpretation about the genesis of the world. For them, the world is neither created exnihilo nor designed from the eternal prime matter by God. In the most general terms, 
the world is defined as the theophany of God through His attributes and modes. The divine attributes, which are also called divine names by Ibn 'Arabi, manifest the essence of God and bridge the gulf between the sensory realm and non-sensory aspects of the same reality.

In understanding Ibn 'Arabi's interpretation of the existence of the world it is necessary to go back to his distinction between the divine presence, the divine attributes and the divine acts. The divine presence represents God's essence in itself without being related to any existent or non-existent outside His essence. The attributes are located in the middle and become the intermediary realm, isthmus (Barzakh) between the divine presence and the divine acts. The third stage in this division, namely the divine acts, include the world and whatever is in it. In this ontological division, we can understand that the world as the divine act confirms to the divine attributes which stand in a causal relationship with it. Regarding the divine attributes, Ibn 'Arabi remarks,

"Certainly, there is but one reality, which embraces all attributes and relations called the divine names. This Reality grants that every Name, infinitely manifest, should have its own reality by which to be distinguished from every other Name. This distinguishing reality is the essence of the Name [the name itself]. In the same way every [divine] gift is distinguished from every other by its own individual quality; for even though all derive from a single source, it is evident that one gift is not the same as another. The cause of that is mutual distinction of Names, there being no repletion on the Plane of Divinity with all its extensiveness. This is the indisputable truth." (Ibn 'Arabi, 1980: p. 68)

Again in the Meccan Revelations, Ibn 'Arabi writes, "Hence, Divine Presence is a name belonging to an Essence, Attributes, and Acts; or, if you like, you can say: to the Attributes of Acts (sifafi 1 ) and the Attributes of Incomparability (sifatanzîh)" (Ibn 'Arabi, 2005: p. 58). The attributes are not modes or existent entities. Rather they are defined as relationships between God's essence and the world. For example, God is the originator and the world as the existent entity is originated. Origination then is an attribute of God and stands between Him and the world. All attributes are infinitely manifest and have their own individuality in the sense that they are different from one another. An attribute cannot be replaced by another because no two attributes are identical however they still belong to a single ontological reality which is God's essence. No attribute has its own reality or can exist by itself except in that to which it is ascribed, because no attribute can subsist in itself. The divine attributes exist in the intermediary stage between God and His theophany and yet constitutes His essence. But the world as a visible manifestation of God is neither God nor His attributes. It is a divine act and the third stage in this ontological system, which derive from the attributes (Ibn 'Arabi, 2005: p. 58). The world and all other existing entities in the world can be traced back to divine attributes and the divine attributes to the essence of God. The world is not different from God's essence in the sense that it 
does not belong to another reality, and then the qualities of the world including its materiality must be the theophany of God through His divine attributes,

"So the world is both carrier (hâmil) and carried (mahmûl). As carrier, it is form (sûra), body (jism), and active (fấi il); as carried it is meaning (mánâ), spirit (rûh), and passive (munfa'i $i$ ). There is no form sensory (mahsus), imaginable (khayâli), or spiritual (mánawi) that is not shaped (taswiya) and balanced ( $t a^{\prime} d i$ ) by God in a manner appropriate to it and to its station and its state; and this takes place before composition (tarkib), i.e., its combination (ijtimấ) with what it carries." (Ibn 'Arabi, 2005: p. 52)

The world as God's act and the manifestation of His attributes carries form and matter. It is also eternal and renewed forever simply because the manifestation of God is eternally re-generating. There is no difference between the potential and the manifested because whatever exist is the manifestation of the divine attributes and the divine attributes constitute God's essence. Nevertheless, the world is not entirely equal to God's essence. The world is a mere theophany and the outward manifestation of the Reality. In this way Ibn 'Arabi's thesis is markedly distant and distinct from any doctrine that identifies the world with God. If God is defined as the totality of the existing entities and nothing else then one can identify the world with God and conclude that Ibn 'Arabi's ontology is rightly pantheism. But God in this ontological system is not the totality of the existing entities. This point becomes clear in our discussion on Spinoza's understanding of God's existence and its relationship with the world in his tripartite ontological system of (substance, attributes and modes). In this system one must examine the causal relationship between these three stages. For Spinoza, nothing exists but one substance which he identifies with God. Substance or God is the only reality that exists in itself while other things, which are not substance, rely on substance to exist. In this way, substance becomes infinite and all other things finite. Substance also has an infinite number of attributes, each of them infinite in kind. "God or substance consist [s] of infinite attributes, each of which expresses eternal and infinite essence, necessarily exist" (Spinoza, 1970: p. 7). In the proof of Proposition X, he states that the infinite attributes constitute God's essence. But out of these infinite attributes we know only two attributes, namely thinking and extension. From the infinite attributes of thinking and extension a series of modes is infinitely manifest. The infinite and eternal nature of these modes are founded on the infinite and eternal nature of these attributes. These modes are divided into immediate infinite modes of extension such as "motion and rest", and of thinking, which is the absolutely infinite intellect, and the world which is a mediate infinite mode. It is not clear whether this mediate infinite mode belongs to extension, thinking or both. But the existing things, for example, particular beings, are finite modes produced by the attributes and their essence does not involve their existence. Therefore, they cannot exist by themselves. The existence, as well as essence of these modes are dependent upon substance. 
The novelty in Spinoza's interpretation of the causal relationship between substance and the modes can be summarised in two points; First, God is not the transient cause of the world and second, God's causality includes materiality of the world. For if we think of the materiality of the world as having a source other than God, then we would conceive of it without God's existence and this is a denial of the existence of a single reality. Spinoza's notion of God's causality insists on the immanent relationship between God and the world. But it is still incorrect to think that Spinoza made no distinction between God and the world. If the world is the mode of the attributes of extension and thinking and God has an infinite number of infinite attributes then it is challenging to equate God with the world. However, the advocacy of God's immanence does not mean that God is in the world but rather the opposite, "Whatever is, is in God, and nothing can exist or be conceived without God" (Spinoza, 1970: p. 11). As a consequence of retaining the singularity of God, Spinoza necessarily denies the independent reality of the world. Hegel, for example, describes this ontological approach of Spinoza towards the world as "Acosmism", (Hegel, 1995: p. 281) in which nothing other than God can possibly be real.

\section{Conclusion}

After this discussion and in the light of Ibn 'Arabi's and Spinoza's respective ontological projects, it becomes clear that God is the only reality wherein nothing exists independent of Him and His existence is all-inclusive. This would necessarily involve the existence of the world and in particular its materiality and its physical reality. In this ontology, distancing God from the world concedes a contradiction and results in the existence of two independent substances. It is also important to know that the identification of God and the world is not without differences. Neither Ibn 'Arabi no Spinoza has advocated the doctrine of absolute identity of God with the world. The identification of God with the world is by no means the equation of God with the world. God, as the necessary being whose essence involves existence cannot be equal with the modes of His existence which are mere possible beings deriving the necessity of their existence from Him.

\section{References}

Aristotle (1995). Metaphysics. In: J. Barnes (Ed.), Complete Works of Aristotle, Vol. 1. Princeton and New Jersey: Princeton University Press.

Chittick, W. C. (1989). Ibn al-'Arabi's Metaphysics of Imagination: The Sufi Path to Knowledge. New York: State University of the New York Press.

Corbin, H. (1981). Creative Imagination in the Sufism of Ibn 'Arabi. Translated from the French by Ralph Manheim, Princeton: Princeton University Press. https://doi.org/10.1515/9781400853670

Curley, E. M. (1969). Spinoza's Metaphysics: An Essay in Interpretation. Massachusetts and Cambridge: Harvard University Press.

https://doi.org/10.4159/harvard.9780674330450 
Hegel, W. F. (1995). Lectures on the History of Philosophy, Vol. 3. Translated by E. S. Haldane and Frances H. Simon, Lincoln and London: University of Nebraska Press.

Ibn 'Arabi (1980). The Bezels of Wisdom. Translation and Introduction by R. W. J. Austin, New Jersey: Paulist Press.

Ibn 'Arabi (2005). The Meccan Revelations, Vol. 1. Translated by William C. Chittick and James W. Morris, Edited by Michel Chodkiewicz, New York: PIR Press.

Knysh, A. D. (1999). Ibn 'Arabi in the Later Islamic Tradition. New York: State University of New York Press.

Netton, I. R. (1980). Allah Transcendent. Surrey: Curzon Press.

Pollock, F. (2005). Spinoza: His Life and Philosophy. London: Elibron Classics Series.

Russell, B. (2000). History of Western Philosophy. London: Routledge.

Spinoza, B. (1970). Ethics. Translated by Andrew Boyle, Introduction by T. S. Gregory. London and New York: Everyman's Library.

Spinoza, B. (1985). Short Treatise on God, Man and His Well-Being. In: Collected Works of Spinoza, Vol. 1, Edited and Translated by Edwin Curley, Princeton and New Jersey: Princeton University Press.

Wolfson, H. A. (1962). The Philosophy of Spinoza, Vol. 1. Massachusetts, and London: Harvard University Press. 